\title{
When fascism met empire in Japanese-occupied Manchuria*
}

\author{
Louise Young \\ Department of History, University of Wisconsin-Madison, 3211 Mosse Humanities Bldg, \\ 455 North Park St, Madison, WI 53706, USA \\ E-mail: louiseyoung@wisc.edu
}

\begin{abstract}
Focusing on the case of Japanese-occupied Manchuria, this article asks what set Japan, Germany, and Italy apart from other empires during the 'fascist moment' from the aftermath of the First World War to the defeat of the Axis powers in 1945. While scholars have examined the politics and culture of fascism in metropolitan Japan, there is virtually no literature on fascist imperialism. Indeed, the consensus term is 'wartime empire' and the dominant framework is of an empire mobilized for total war. One of the goals is to think through what the concept 'fascist imperialism' might mean and what the Japanese case might contribute to its definition. Detailed comparison with Germany and Italy is beyond the scope of this article, which builds a definition of fascism around four core elements drawn from the Japanese case: the ideology of Asianism and its vision for Japanese leadership over a regional movement of anti-colonial nationalisms; hyper-militarism that went well beyond military imperialism pursued since the late nineteenth century and that constituted a new celebration of military action and the aesthetics of violence; red peril thinking that propelled the creation of a police state targeting communist intellectuals, politicians, and labour activists within the archipelago as well as communist nationalists in the empire; and radical statism, which signified the turn to the state as the spear tip and staging ground of action to address the crisis. All four dimensions of fascism in Japan intensified in the process of territorial expansion from 1931 to 1945, and linked transformations across the nation-state-empire.
\end{abstract}

Keywords anti-communism, Asianism, fascism, Japan, Manchukuo, Manchuria, militarism, red peril

Historians often view Japanese imperialism in exceptional terms. Race and culture set Japan apart from the imperial powers of the West; its drive for world power challenged four centuries of European dominance in Asia. ${ }^{1}$ And yet, the Japanese case has much in common with other empires of modern times. In particular, the commonalities of the three Axis empires offer a number of intriguing parallels. All three considered themselves outsiders, who embarked on

\footnotetext{
* I would like to thank Kim Brandt, Daniel Hedinger, Reto Hofmann, Viren Murthy, Sven Reichardt, and the anonymous readers for the Journal for their helpful comments.

1 The classic expression of this is Mark Peattie's reference to Japan as an 'anomaly of modern history': Mark R. Peattie, 'Introduction', in Ramon H. Myers and Mark R. Peattie, eds., The Japanese colonial empire, 1895-1945, Princeton, NJ: Princeton University Press, 1984, p. 6.
} 
empire-building during the hyper-imperialism of the late nineteenth century and entered an inter-state system where established powers such as Britain and France appeared to hold the advantage. The shared perception that they had started out behind in the scramble for territory in Africa and Asia contributed to ways in which all three found fault with the existing economic and legal framework of imperialism, and particularly the institutions created after the First World War. By the 1920s, the language of 'have not' and 'proletarian' nations began to appear in German, Italian, and Japanese discussions of the world order. Such discussions defended their expansionisms as a matter of national survival and called for an equal share of world resources, denouncing as hypocrisy efforts to obstruct them while leaving in place the vast colonial empires established under the old order. From the mid 1930s, diplomatic and intellectual ties between the three Axis powers built on this foundation, and provided space for exchange of the norms and forms of what might be called 'fascist imperialism'.

This article explores the concept of fascist imperialism as it applies to the case of Japan. While scholars have examined the politics and culture of fascism in metropolitan Japan, there is virtually no literature on fascist imperialism. Indeed, the consensus term is 'wartime empire' and the dominant framework is of an empire mobilized for total war. ${ }^{2}$ One of my goals is to think through what this concept might mean and what the Japanese case might contribute to a definition of fascist imperialism. Detailed comparison with Germany and Italy is beyond the scope of this article; rather, I attempt to build a definition of fascism around four core elements drawn from the Japanese case.

The first was the ideology of Asianism that envisioned Japanese leadership over a regional movement of anti-colonial nationalisms. Asianism sought a regional order that rejected Western ideals of Soviet internationalism and British liberal imperialism and aimed to drive the West out of Asia. Japan's claim to be shepherding the creation of an independent, multi-racial state in Manchukuo was part of this effort, as was the articulation of a political ideology for Manchukuo - what I call Asian-style fascism - that positioned itself as a third way between democracy and socialism. Thus, the first characteristic of fascist imperialism is Asianism as a challenge to and rejection of the Western-dominated geopolitical world order.

The second element was hyper-militarism, a phenomenon that connected the inside and outside of fascist imperialism. Beginning with the Manchurian Incident of 1931, Japan's military became an instrument of radicalism and terror both at home and in the empire. The army seized control of Japan's sphere of influence in China from civilian power holders such as the South Manchurian Railway (SMR) and the Kwantung Governor-General, and took over the government in Tokyo by sidelining civilians and excluding party politicians from the central organs of state control. Once in power, the army took the lead in green-lighting further aggressive military expansionism, and increasingly suspended political liberties in the name of putting society on a total war footing. In this sense, hyper-militarism went well beyond projects of military-led modernization and military imperialism pursued since the late nineteenth century and constituted a new celebration of military action and the aesthetics of violence that was distinctly fascist.

The third feature of fascist imperialism was red peril. Anti-communism suffused army thinking throughout the 1920s and 1930s, and propelled the creation of a police state targeting

2 The term 'wartime empire' was coined by Peter Duus, Ramon H. Myers, and Mark R. Peattie, eds., The Japanese wartime empire, 1931-1945, Princeton, NJ: Princeton University Press, 1984. 
communist intellectuals, politicians, and labour activists within the archipelago, as well as communist nationalists in the empire. Red peril thinking became weaponized through military operations to contain the Soviet Union, from the Siberian Intervention after the First World War to the undeclared war of the late 1930s. The mutually reinforcing connections between anti-communist foreign policy, military strategy, and governmentality emerged precisely because the threat of communism to the Japanese state spanned global and regional politics: colonial politics in Korea, Taiwan, and China, as well as domestic politics. As I will argue, fascist alliances and fascist governmentality emerged as the answer to that threat.

The fourth aspect of fascism in Japan was what I call radical statism. What Asianism, hypermilitarism, and red peril thinking all held in common was the turn to the state as the agent of salvation. Fascism at home and in the empire made the state into the spear tip and the staging ground of radical reform. Driving the embrace of radical state solutions were events both on the world stage and in the domestic arena. The rise of anti-colonial nationalism in Asia, the breakdown of Great Power cooperation in China, and the global economic crisis of the early 1930s exposed the inadequacy of existing strategies and institutions. Social unrest and economic paralysis at home cried out for bold and immediate solutions. These concatenating crises convinced a broad range of stakeholders to put their faith in the state and in radical solutions from the fascist toolkit. Like the other three dimensions of fascism in Japan, radical statism intensified in the process of territorial expansion from 1931 to 1945 . As I will argue, all four elements of fascist imperialism linked transformations across the nation-state-empire.

'Fascism' is a vexed and emotional word, especially in Asia, where disputes over the use or misuse of the term have evaded consensus for nearly a century. We have arrived at a moment where debates about the definition of fascism have again gained currency, driven by the proliferation of right-wing nationalist movements across the globe. The widespread trafficking in neo-fascist thought and policy press us to rethink what the original fascist moment represented. The question of whether Japan was fascist is a fraught one, which has often foundered on the substantive differences between political regimes in Germany, Italy, and Japan. While much of the earlier literature on comparative fascism looked at politics, states, and political leadership, the starting point of this special issue is to re-engage with the issue of comparability upon the site of empire. By expanding the scope of our investigative terrain, the problem of fascist imperialism brings new material to the table and opens up possibilities for theorizing the structures and dynamics of fascism. In this spirit, my article will examine Japan's occupation of Northeast China from 1931 to 1945 to ground a thought experiment for a new understanding of fascism.

\section{What is fascist imperialism? A critical historiography of the debate over Japanese fascism}

The literature on Japan's wartime empire has largely given the question of fascism a pass, much as ongoing debates over fascism in Japan tend to ignore the imperial dimension. But any framework for analysing the connections between empire and fascism - and the purchase that the concept 'fascist imperialism' might have for Asia - builds on the conceptual vocabulary and accumulated insights developed over nearly a century of study. I base my own definition on this intellectual genealogy. 
The debate over Japanese fascism in both English and Japanese is inherently political and the stakes have changed over time. In the 1930s Japanese Marxists wanted an effective strategy to defeat the wartime state, and their analysis of the rise of fascism was tied to the outline of a programme for revolution. In the 1950s Japanese intellectuals took as their starting point the condemnation of fascism and the wartime regime. Debate revolved largely around the question of who was responsible for the road to war, as scholarship aimed to expunge fascism from the body politic, root and branch. In the 1960s and 1970s American cold warriors sought to recast Japan on the side of democracy and liberal capitalism. They rejected the fascist label, instead theorizing a division between weak democracies (with evolutionary potential) and totalitarian police states (such as Nazi Germany and the USSR). In the final decades of the twentieth century, economic triumphalism and the global dominance of Japanese exports generated new interest in pre-war militarism, expansionism, and fascism as a point of reference to contemporary forms of soft and hard power. Cultural critique of fascism offered a way to think through the ideological resonances between early and late twentieth-century Japanese power in the world. If our stakes in the debate over Japanese fascism today are to understand the relationship between the fascism of the 1930s and the neo-fascism of the current conjuncture, one striking parallel between these historical moments is the intensification of inter-state competition in the world economy, the attention to 'winners and losers' of (neo-)liberalism, and the global synergies and circulations of (neo-)nationalist ideologies.

Some of the richest insights into the problem of fascism in Japan were contributed by Japanese Marxist historians, who in the 1950s introduced the concept of 'emperor-system fascism' to explain the wartime state. ${ }^{3}$ Picking up on analyses of the peculiarities of Japanese fascism that aimed to chart a path to revolution in the 1930s, in the 1950s Marxists were celebrated for their prescience and courage in opposing the war. 'Emperor-system fascism' posited the turn to fascism from around the Manchurian Incident of 1931. While the lineaments of absolutism and the 'emperor system' were established with the Meiji constitutional order of the late nineteenth century, which vested sovereignty in the emperor rather than the people, over time the development of Japanese capitalism adapted the imperial state to conform to liberal markets and democratic politics. This arrangement worked more or less until the depression of the late 1920s spurred a political-economic sea change. As agents of this shift, the bourgeoisie abandoned their support of a political party system paralysed in the face of the global crisis of capitalism. In order to salvage monopoly capitalism, they gave fascist powers to the state to expand and centralize government control over politics. These powers were expressed in the crackdown on liberal and left-wing thought in universities and the mass arrests of communists, in the termination of party cabinets from 1932 and the increasing insulation of executive decision-making from democratic control, and in the rising collusion between the army and big business in their sway over state bureaucracy. It was also expressed, significantly, in the unleashing of the Imperial Army across Asia in order to shore up the interests of financial-industrial combines. The Marxists summarized the basic contours of their theory of fascism as 'military aggression abroad; political repression at home'.

3 For an introduction to Japanese Marxist scholarship in English, see Hatano Sumio, 'Japanese foreign policy, 1931-1945: historiography', in Sadao Asada, ed., Japan \& the world, 1853-1952: a bibliographic guide to Japanese scholarship in foreign relations, New York: Columbia University Press, 1989, pp. 217-39; Germaine A. Hoston, Marxism and the crisis of development in prewar Japan, Princeton, NJ: Princeton University Press, 1989, pp. 179-222, 256-64. 
For my purposes, two aspects of the Marxist formulation of 'emperor-system fascism' are important for a theory of fascist imperialism. First, while this scholarship focuses exclusively on the metropolitan state and economy, the connection between 'repression at home and aggression abroad' offers us a number of entry points to an analysis of fascist imperialism. These include the imperial origins of fascism and the global crisis as determinant of the fascist turn. Second, the Marxist formulation draws our attention to the development of new instruments of state power such as political surveillance, thought control, and spiritual mobilization. New forms of colonial state power such as the planned economy were deployed in rapid succession in Manchukuo, where many of the tools of a national defence state were tested out before being brought back to metropolitan Japan.

Maruyama Masao challenged the Marxian interpretation of fascism in his enormously influential series of essays on Japanese politics, published in English under the title Thought and behavior in modern Japanese politics. Maruyama agreed with the Marxists in labelling Japan fascist, but sought to look beyond the structure and form of the state and think instead about the fascist movement and its core ideas. He examined the radical military officers who were involved in political assassinations and coup attempts in the early 1930s in an effort to cleanse the state of corruption and restore authority to the emperor. He analysed the wartime leadership that assumed power in the late 1930s, who used the imperial symbol as cover to dictate initiatives on a weak parliament and dramatically expand state power over society.

Maruyama's theory of fascism is captured in the memorable turns of phrase 'fascism from below' and 'fascism from above'. The first refers to the wave of political violence between 1931 and the attempted coup of 1936 orchestrated by young officers and the radical right, the latter to the adoption of a series of policies modelled on National Socialism in the late 1930s, a policy shift engineered by establishment insiders in the wartime leadership. ${ }^{4}$ For my purposes, what this distinction helps illuminate is the importance of the state as the fulcrum of the fascist movement. Maruyama has thus laid the ground for analysing radical statism: why radicals outside and inside government saw in the state the possibility to push through their programme for resolving the agrarian crisis, the imperial crisis, the economic crisis, the political crisis, and the military crisis. In proposing radical statism as a characteristic of fascism in Japan, one of the questions I will be exploring is why the state became the staging ground and the agent of radical reform. Examining the imperial dimension of fascist thought and radical statism as it played out in Manchuria will provide some answers to this question.

A third line of argument in the fascism debate is represented by what might be called the 'rejectionists': scholars such as Itō Takashi who dismissed the applicability of the fascist label to the Japanese case. They also focused on key differences, including the lack of a charismatic leader like Hitler or Mussolini, and the fact that the government was not taken over by outsiders or a mass movement but remained in the hands of the old guard of political elites. In Itō's view, the political history of the 1930s was better understood in terms of a contest

4 Maruyama Masao, Thought and behavior in Japanese politics, ed. Ivan Morris, London and New York: Oxford University Press, 1969. Maruyama is probably the most frequently cited Japanese scholar in English, even by those who disagree with him. See Rikki Kersten, Democracy in post-war Japan: Maruyama Masao and the search for autonomy, London: Routledge, 1996, pp. 13-48, 137-63. For a critical view, see Gregory J. Kasza, 'Fascism from below? A comparative perspective on the Japanese right 1931-1936', Journal of Contemporary History, 19, 3, 1984, pp. 607-29; Gregory J. Kasza, 'Fascism from above? Japan's kakushin right in comparative perspective' in S. U. Larsen, ed., Fascism outside Europe: the European impulse against domestic conditions in the diffusion of global fascism, New York: Columbia University Press, 2001, pp. 183-232. 
between left and right radicalism that sought to overturn the status quo and an establishment conservatism that sought to preserve it. ${ }^{5}$

When American historians picked up on the Japanese fascism debate in the 1970s, they largely agreed with the rejectionists in stressing that traditional political elites remained in power and long-standing institutions endured. They floated a number of alternative frameworks of their own for characterizing Japanese wartime politics: corporatism, militarism, and authoritarianism. ${ }^{6}$ This string of new labels led into what Rikki Kersten called a 'quagmire of particularism' that effectively killed off further interest in the subject for decades.' Nevertheless, by pointing out the essential continuities in Japanese politics, the 'rejectionists' also called into question the argument of a fascist rupture and the efficacy of domestic challenges to the status quo.

I believe that we can productively revisit the questions raised here of ruptures and continuities in politics and ideology by scaling up and placing Japan in a global geopolitical setting. Domestic politics were profoundly influenced by changes in the international political regime, both new structures put in place after the First World War and the trends towards protectionism after the global crash of 1929. Examining the major shifts in Japanese foreign policy from 1931, I will argue for a fascist rupture that began in the empire and continued at home. This rupture emerged through a challenge to the status quo on a global scale and was followed by the fascistization of the Japanese polity through the incorporation of new forms of corporatism, militarism, and authoritarianism, as suggested by the 'rejectionists', but whose sum went well beyond any single one of these features.

In the past decade or so, American scholars have gone back to the question of Japanese fascism in a stream of new works. Harry Harootunian's influential Overcome by modernity located fascism in cultural discussions of the interwar period, especially in the search for authenticity and community. Rather than drawing a distinction between liberal, modernist thought on one hand and reactionary, fascist thought on the other, Harootunian draws a direct line between the two. As he argues, modernist art and philosophy of the constructivists, Marxists, and others was a response to the sensation of being 'overcome by modernity'. But modernism gave rise to a secondary discourse on the social, expressed in fascist literature and philosophy of the folklore movement, literary romanticism, and the Kyoto school project to 'overcome modernity'. ${ }^{8}$ A ground-breaking volume edited by Alan Tansman, The culture of Japanese fascism, included essays on literary movements, philosophy, material culture, architecture, expositions, and even dogs - 'fascism's furry friends'. ${ }^{9}$ Like other studies at the turn of the new millennium, this work highlights the importance of ideas and ideology, aesthetics, and popular culture. ${ }^{10}$

5 Itō Takashi', Shōwa seiji shi kenkyū e no hito shikaku (One perspective on the political history of the Showa period)', Shisō, 624, June 1976, pp. 949-62.

6 For the American rejectionist school, see Peter Duus and Daniel Okamoto, 'Fascism and the history of prewar Japan: the failure of a concept', Journal of Asian Studies, 39, 1, 1979, pp. 65-76.

7 Rikki Kersten, 'Japan', in R. J. B. Bosworth, ed., The Oxford handbook of fascism, Oxford: Oxford University Press, 2004, pp. 526-44.

8 Harry Harootunian, Overcome by modernity: history, culture, and community in interwar Japan, Princeton, NJ: Princeton University Press, 2002.

9 Alan Tansman, ed., The culture of Japanese fascism, Durham, NC: Duke University Press, 2009. The essay on dogs is Aaron Skabelund, 'Fascism's furry friends: dogs, national identity, and the purity of blood in 1930s Japan', pp. 155-84.

10 See also Alan Tansman, The aesthetics of Japanese fascism, Berkeley, CA: University of California Press, 2009. This new trend in the history of fascism was anticipated by Miles Fletcher's 1982 study, The search for a 
New comparative research has pointed attention to connections between prominent fascist thinkers in Japan, Germany, and Italy and has underscored mutual influences between government initiatives in economic, political, and cultural spheres. ${ }^{11}$ Collectively this recent work has helped explain the fascist moment by showing us that similar ideas gained traction in a variety of places during a time of global crisis; and that the cultural and intellectual context for the turn to fascism was at once domestic and international. Equally importantly, it redirected the frame of comparative analysis from typologies or taxonomies to the transnational circulation of ideas - and the institutions, social networks, and diplomatic alliances that constitute the conditions of possibility for such intellectual engagement. Building on these insights about culture, aesthetics, and thought as a critical site of analysis, my article asks: what happens to these ideas and synergies when incubated in a colonial/imperial context?

The insights gleaned from this selective historiography of the debate on Japanese fascism can be distilled into three overarching questions that help focus our analysis on the site of empire. First, how did changes in global and regional geopolitics catalyse the rise of fascism? The strains in the liberal world order and the rise of anti-colonial nationalism after the First World War were primary causes of a widespread sense of crisis and heightening imperial rivalries in Asia. It was the losers in the global competition - the 'have nots' or 'have lesses' who, especially in the context of global economic crisis, made sharp fascist turns. This leads to a second question: if we posit that the fascist turn was driven by imperial ambitions, what was happening on the ground in the empire? Because fascism relied on authoritarian control, the suspension of the rule of law, the fetishizing of power, scapegoating racial others, cults of violence, and so on, the colonial context offered the perfect setting to develop all of these technologies. What sorts of fascist ideas, practices, and institutions were produced in Japanese-occupied Manchuria? Finally, what was the relationship between fascism in the empire and fascism at home? In all of the four defining elements of fascism proposed here Asianism, hyper-militarism, red peril, and radical statism - events in the empire caused, reinforced, and accelerated these tendencies at home and the reverse was also true.

As I will argue, the history of the Japanese occupation of Northeast China and the creation of Manchukuo demonstrates the synergy and interdependence between imperial expansion and the development of the fascist programmes throughout the nation-empire-state. This includes the embrace of Asianism as the loadstar for regional autarky and the New Order in Asia, the mobilization for total war and glorification of the military, and the creation of an empire-wide anti-communist police state, as well as the fetishization of state power and magical thinking about state omnipotence.

\section{Anti-colonial nationalism and the turn to a third way of Asian-style fascism}

In the first instance, the eventfulness of the First World War set up the conditions of possibility for fascism in Asia. The rise of the radical right and the widespread appeal of national socialist

new order: intellectuals and fascism in prewar Japan, Chapel Hill, NC: University of North Carolina Press, 1982.

11 Janice Mimura, Planning for empire: reform bureaucrats and the Japanese wartime state, Ithaca, NY: Cornell University Press, 2011; Reto Hofmann, The fascist effect: Japan and Italy, 1915-1952, Ithaca, NY: Cornell University Press, 2015. 
ideas throughout the globe emerged in the unsettled aftermath of the Great War, whose catastrophic losses and demonstrated failures of states everywhere emboldened radical challenges to traditional power structures. In Europe, revolutionary and evolutionary socialisms, shattered empires, shattered armies, and shattered economies together nurtured the rise of fascism in Italy and national socialism in Germany. The impact of the war was experienced differently in Asia, where wartime agreements, as well as the Paris and Washington Conferences of 1918 and 1921-22, overturned regional geopolitics and discredited the existing diplomacy of imperialism. ${ }^{12}$ Asian nationalists attended the Paris Peace Conference and reported in the nationalist press on Woodrow Wilson's endorsement of the principle of national self-determination and the territorial settlements that embodied it. China, Korea, India, and Indo-china all generated powerful anti-colonial nationalist movements that set both ideas and organizational models in global motion. ${ }^{13}$ The rising tide of nationalism brought the regime of liberal imperialism in Asia under siege, challenging the unequal treaties that underpinned foreign dominance of China's political economy, and the ideology of civilization that justified colonialism in India and Korea. In the process, Asian nationalists called out the imperialism of so-called 'free trade' and condemned white supremacy on the world stage.

As the ground shifted beneath their feet, Japanese statesmen cast about for a means to reconstruct the imperial project to make common cause with anti-colonial nationalism. What followed was a series of experiments in new forms of dominance that borrowed nationalist critiques of Western racism and the liberal world order. Under the banner of 'Asianism' and a Japanese-led 'Co-prosperity Sphere', these experiments were designed to sharply distinguish the Japanese empire from its Western counterparts. The state of Manchukuo, established in 1932, was the first expression of this shift. ${ }^{14}$ After a series of military campaigns to drive the local Chinese warlord, Zhang Hseuh-liang, out of Northeast China, Japan's Kwantung Army enlisted powerful rivals of Zhang among the landlord class to organize an 'independence movement', spirited the last descendant of the Chinese imperial family, $\mathrm{Pu} \mathrm{Yi}$, up from the south to reclaim the throne, and created the nominally independent state of Manchukuo. Japan quickly recognized Manchukuo and signed a mutual defence treaty, making the Kwantung Army responsible for its national security. Manchukuo became the model for a new kind of 'imperialism without colonies', a form of client state that could accommodate nationalist demands for sovereignty and self-determination but that ensured Japanese political control. ${ }^{15}$

12 To read more on the aftermath of the First World War for Japan, see Frederick Dickinson, World War One and the triumph of a 'new Japan', 1919-1930, Cambridge: Cambridge University Press, 2015; Thomas Burkman, Japan and the League of Nations: empire and world order, 1914-1938, Honolulu, HI: University of Hawai'i Press, 2007; Akira Iriye, After imperialism: the search for a new order in the Far East, 1921-1930, Cambridge, MA: Harvard University Press, 1965.

13 On the nationalist movement in Vietnam, Korea, and China, see Mark Bradley, Imagining Vietnam and America: the making of postcolonial Vietnam, 1919-1950, Chapel Hill, NC: University of North Carolina Press, 2000; Frank Baldwin, 'Participatory anti-imperialism: the 1919 independence movement', Journal of Korean Studies, 1, 1979, pp. 123-62; Rana Mitter, A bitter revolution: China's struggle with the modern world, Oxford: Oxford University Press, 2005.

14 On this shift, see Prasenjit Duara, Sovereignty and authenticity: Manchukuo and the East Asian modern, Lanham, MD: Rowman and Littlefield, 2003.

15 Peter Duus, 'Imperialism without colonies: the vision of a greater East Asian co-prosperity sphere', Diplomacy and Statecraft, 7, 1, 1996, pp. 54-72. While the widely used term 'puppet state' stresses that Manchukuo independence was fake, a number of studies have wrestled with the ambiguities of sovereignty in Japaneseoccupied Manchuria. See David Tucker, 'Colonial sovereignty in Manchuria and Manchukuo', in Douglas Howland and Luise White, eds., The state of sovereignty: territories, laws, populations, Bloomington, IN: Indiana University Press, 2009; Suk-Jung Han, 'The problem of sovereignty: Manchukuo, 1932-1937', Positions: East Asia Cultures Critique, 12, 2004, pp. 457-78; Yamamuro Shin'ichi, Kimera: Manshükoku no 
Guided by Japan, state-making and nation-building in Manchukuo provided a staging ground for the development of Asianism as a constituent of fascist imperialism.

One dimension of Asianism developed in Manchuria was the political ideology of a third way between the liberal imperialism of Great Britain and Comintern internationalism of the Soviet Union, an ideology I am calling Asian-style fascism. The journalist and scholar Tachibana Shiraki helped craft the ideas behind the political philosophy of Manchukuo in his journal, Manshü hyōron (Manchurian Review). Tachibana established a reputation in the 1920s as a left-wing economist, tracking class struggle in China and the fortunes of the Chinese Communist Party, before he recanted his faith in socialism and allied himself with the Kwantung Army. As an expert Sinologist, he was deeply immersed in Chinese intellectual history, Confucian philosophy, and contemporary Chinese politics, knowledge on which he drew to promote two concepts underpinning Manchukuo: the adaptation of the Confucian doctrine of the 'Way of the King' to justify the dictatorship of the imperial state, and appropriation of the Chinese Republican concept of 'five races under one union' as the slogan for the state-controlled mass party, the Kyōwakai. ${ }^{16}$ In the empowerment of the mass party, the calls to reject both socialism and liberalism, and the fusing of primordial kingship and contemporary dictatorship, the political ideology of Manchukuo laid down a blueprint for Asian-style fascism.

The architects of Manchukuo borrowed the idea of the 'Way of the King' from Sun Yat-sen, a leader of the revolution that overthrew the Qing dynasty in 1911, who also helped establish the Republic of China in 1912 and the Nationalist Party (Kuomintang) soon after. Sun Yat-sen deployed the term in the mid 1920s to contrast the evils of Western (especially British) imperialism with the promise of pan-Asianism modelled on the Sino-centric tribute system. As he argued, the British used a 'cult of force' and the 'Way of the Despot' to oppress Asia (the Rule of Might), while traditional China used the 'Way of the King' to persuade weaker countries to join the tribute system (the Rule of Right). ${ }^{17}$ Again according to Sun, Russian renunciation of treaty port rights acquired through gunboat diplomacy aligned Russia with Asia, while Japan stood at a crossroads: it could continue along the path of occidental despotism and prey upon China, or it could turn to the Asian way and forge Sino-Japanese amity.

The governing ideology of Manchukuo picked up on these ideas, locating the philosophical genealogy of the state in Chinese tradition. Tachibana explicitly engaged Confucian, liberal, and socialist philosophies to make his case, and it is worth noting here that he himself was a convert to the Asian 'third way' as one who had earlier advocated precisely the democratic reforms and socialist ideals he now rejected. ${ }^{18}$ Following Sun Yat-sen, the promulgation of the 'Way of the King' in Manchukuo represented Japan's choice of pan-Asianism and

shōzō (Chimera: a portrait of Manchukuo), Tokyo: Chūō Kōronsha, 1993, translated by Joshua Fogel as Manchuria under Japanese domination, Philadelphia, PA: University of Pennsylvania Press, 2006.

16 Lincoln Li, The China factor in modern Japanese thought: the case of Tachibana Shiraki, 1881-1945, Albany, NY: State University of New York Press, 1996; Louise Young, Japan's total empire: Manchuria and the culture of wartime imperialism, Berkeley, CA: University of California Press, 1999, pp. 282-91.

17 Roger H. Brown, 'Sun Yat-sen: “pan-Asianism”, 1924', in Sven Saaler and Christopher W. A. Szpilman, eds., Pan-Asianism: a documentary history, volume 2: 1920-present, Lanham, MD: Rowman \& Littlefield, 2011, pp. $75-85$.

18 For discussion of fascism in China, see Frederic Wakeman, Jr, 'A revisionist view of the Nanjing decade: Confucian fascism', in F. Wakeman and R. L. Edmonds, eds., Reappraising republican China, Oxford: Oxford University Press, 2000, pp. 141-78; Dooeum Chung, Elitist fascism: Chiang Kaishek's blueshirts in 1930s China, Aldershot: Ashgate, 2000; and Maggie Clinton, Revolutionary nativism: fascism and culture in China, 1925-1937, Durham, NC: Duke University Press, forthcoming. 
Sino-Japanese friendship against the despotic model of Western imperialism. As Tachibana and others explained, Pu Yi stood in as the 'sage-king' of Confucian philosophy and represented the head of a state organized along Confucian principles. Under his benevolent rule, Manchurians were emancipated from the military despotism of the former warlord regime and became free to flourish in a 'society of the great union'. Thus the Confucian-inspired Kingly Way of Manchukuo replaced the military despotism of Zhang Hseuh-liang with Pu Yi's benevolent monarchy/enlightened dictatorship, part of the timeless cycle of political renewal.

At the same time, Manchukuo represented a modern Asian alternative to Western political models of liberalism and socialism. With their direct, spiritual connection to $\mathrm{Pu} \mathrm{Yi}$, the Manchurian people had no need of institutions of representative government developed for Western civilization. This idea of a state form that mediated the direct connection between emperor and people, and that categorically rejected individualism, resonated with the mobilization of the imperial symbol in the service of fascism within metropolitan Japan. Both the archaic identification of nation with emperor (Manchuria was the homeland of the Qing dynasty), and the charismatic unity of king and people, was central to the 'imperial way' philosophy circulating among radical officers and the extremist right. Japan's restoration of 'the last Manchu emperor' reverberated with demands for a 'Showa restoration' of imperial power in Japan; the pomp and pageantry surrounding Pu Yi was connected to a revitalized cult of imperial rule in Korea and a stage-managed set of official visits and arranged marriages between the imperial houses of the New Order.

Japanese planners also borrowed the idea of 'harmony of the five races' (gozoku kyowa) from Chinese political philosophy to shore up Manchukuo. The official flag of Manchukuo mimicked the flag of the Chinese Republic, referring to 'five races under one union'. While the Chinese flag was designed as five horizontal bands each representing one ethnic group (red for Han, yellow for Manchu, blue for Mongol, white for Hui, and black for Tibetan), the Manchukuo flag placed four bands (red for Japanese, blue for Han Chinese, white for Mongols, and black for Koreans) into the top left corner on a field of yellow (representing the Manchus). The flag symbolized the Manchukuo philosophy of 'racial harmony' and the multi-ethnic state. This represented the first articulation of official Asianism as a cornerstone of the wartime empire, and the symbolic continuity with Chinese republicanism was a clear gesture to Sino-Japanese partnership. Thus, the political ideology of the new state - both the philosophy of 'racial harmony' and imperial sovereignty under the last Manchu emperor - helped set up a blueprint for Asianism in newly conquered territories in China and Southeast Asia: common cause with anti-colonial nationalism, and nominal sovereignty under a Japanese-led alliance of Asian nations.

As an organizational vehicle for the multi-ethnic state, the Kwantung Army built the mass party called the Kyōwakai (in English, the Concordia Association) in 1933 and 1934 to mobilize all Manchurian subjects, down to the household level. The Kyōwakai was pitched as an organ of multi-ethnic cooperatism, racial equality, and local self-government. It explicitly rejected the divisiveness of political parties, as well as class control over political institutions. In Tachibana's words, the Kyōwakai promised to bring about a 'society controlled by producers rather than capitalists'. It was a party of the masses, which he claimed would lead to peasant empowerment by organizing all peoples into collective self-governing units that decentralized power even as they channelled the direct, spiritual connection between Emperor Pu Yi and his people. ${ }^{19}$

19 Li, China factor, pp. 45-75; Young, Japan's total empire, pp. 282-302; Brown, 'Sun Yat-sen', pp. 76-7. 
Much like the idea of the Kingly Way, the Kyōwakai established a blueprint for Asian-style fascism, a third way that renovated Asian political institutions while skirting the models of liberal pluralist democracy on the one side and the socialist-worker-party state on the other. Both ideas anchored the appeal of Asianism in the wartime empire and helped spread the Manchukuo model of colonial sovereignty throughout China and Southeast Asia. In this way Asian-style fascism became a defining feature of Japan's wartime empire, both the ideology of Asianism and the colonial sovereignty of puppet states. Propelled by the regional geopolitics of anti-colonial nationalism in the wake of the First World War, Manchukuo represented Japan's first experiment with fascist imperialism and its attempt to reconcile nationalist demands for political rights with the protection of Japanese imperial interests.

\section{Hyper-militarism and the dialectic of the internal and the external}

Much like Asianism and colonial sovereignty, hyper-militarism was elemental to fascism in Japan. As Harry Harootunian notes, there is something quixotic in the attempt to differentiate Japanese militarism from German and Italian fascism, as if fascist movements everywhere did not fetishize the military. ${ }^{20}$ In Japan, the affinity of fascism with militarism connected events at home and in the empire, as military expansionism from the early 1930s helped drive the fascist movement in Tokyo and was a major determinant of the fascistization of the state. Moreover, while military imperialism was not limited to fascist states or fascist periods, military expansionism changed its quality and intensity under fascism. Radicalization of military doctrines, a vastly expanded political role for the military, and the political aesthetics of violence became iconic features of the fascist empires that set them apart from earlier instances of military imperialism. Japan's fascist imperialism was defined by the rise of army control over the state, as well as an acceleration of military imperialism, processes that were mutually implicated. Fascist imperialism included a cult of militarism that suffused popular culture, as well a cult of the sword and the bayonet inside and outside the army, all part of the aestheticization of violence that intensified across the 1930s. ${ }^{21}$

The acceleration from militarism to hyper-militarism was particularly clear in the Japanese case. Military expansionism was deployed as a strategy of modernization from the late nineteenth century, but tensions triggered by the First World War and its aftermath challenged army dominance in politics and the empire. In the crisis atmosphere of the late 1920s and early 1930s, military activists struck back, launching a rapid series of violent conspiracies in Manchuria and Tokyo aimed at reclaiming command. On 18 September 1931, a clique of Kwantung Army officers staged an explosion on the Japanese railway track in Mukden and left evidence incriminating Chinese troops. The alleged Chinese attack became the pretext for the Kwantung and Korean armies to launch an invasion of Manchuria, acting without authorization from the high command in Tokyo to mobilize their troops, bomb the city of Jinzhou, and attack the Chinese troops of Zhang Hseuh-liang. The series of independent actions carried

20 Harootunian, Overcome by modernity, p. xxvii.

21 A source book on military history with good bibliographic entries is Louis G. Perez, Japan at war: an encyclopedia, Santa Barbara, CA: ABC Clio, 2013. For an overview of recent scholarship in Japan, see Tsutsui Kiyotada, ed., Fifteen lectures on Showa Japan: road to the Pacific War in recent historiography, Tokyo: Japan Library, 2016. 
out by the Kwantung Army between 1931 and 1933 became known as the Manchurian Incident. $^{22}$

Meanwhile back in Tokyo, in March 1931 plans for a coup d'état by a group of officers in the 'Cherry Society' fell apart at the last minute, though they regrouped for a second attempt in October, again halted at the eleventh hour. In the spring of 1932 the 'Blood Pledge League' drew up an assassination list that included business and political leaders; they executed the former finance minister Inoue Junnosuke and the head of the Mitsui zaibatsu, Dan Takuma, before the ringleaders were arrested. On 15 May, remnants of the Blood Pledge League joined army cadets in another coup attempt, assassinating Prime Minister Inukai Tsuyoshi and launching abortive assaults on several government buildings before surrendering to the police. The wave of army terror culminated in the most spectacular and audacious coup attempt yet on 26 February 1936. Under the leadership of junior officers, 1,400 troops seized central Tokyo, killed several members of the government and their guards, and declared martial law with the support of sympathetic senior officers. But after several days of tense standoffs between different factions of the military, the coup opponents prevailed and forced the rebels to stand down. ${ }^{23}$

What was striking about this wave of army violence was the collective failure of domestic terrorism to attain the stated goal of regime change. ${ }^{24}$ By other measures the conspirators achieved some success: sympathetic senior officers used the threat of junior officer instability to great effect to blackmail bureaucratic opponents within the government; patrons of the rebels publicized their 'patriotism' and 'selflessness', and the nobility of their failure through show trials and publicity stunts. But after the 26 February Incident came dangerously close to success, the army cleansed the ranks of officers allied to the rebel faction, bringing an end to the insurgents' dream of purging the state of 'traitors around the throne' and a 'Showa restoration' of imperial power. In stark contrast to this domestic story, the conspiracy in Manchuria worked to spectacular effect, placing the army in firm command of imperial policy in China and bringing a wave of congratulatory coverage in the mass media.

The military takeover of Manchuria provided the Kwantung Army with a new set of opportunities for expanding its power: over a vastly expanded territory, over foreign policy in China, and over the apparatus of rule in Manchuria. From a tiny foothold in the Kwantung Peninsula in South Manchuria, the Kwantung Army now exercised authority over the four provinces of Northeast China and grew from one division and an artillery battalion into peak strength of twelve divisions in 1941. Over the course of the Manchurian Incident the Kwantung Army sidelined the Foreign Ministry and the South Manchurian Railway (SMR) from the mechanisms of administration over Manchukuo, and impeded possibilities of diplomatic conciliation with the Republic of China. This 'shoot first, ask questions later'

22 Mark Peattie, Ishiwara Kanji and Japan's confrontation with the West, Princeton, NJ: Princeton University Press, 1975, remains the classic study.

23 For accounts of military radicalism that stress that Manchurian connection, see Takehiko Yoshihashi, Conspiracy at Mukden: the rise of the Japanese military, New Haven, CT: Yale University Press, 1963; and Sadako Ogata, Defiance in Manchuria: the making of Japanese foreign policy, 1931-1932, Berkeley, CA: University of California Press, 1964. On the 26 February Incident and factionalism within the armed forces, see Ben-ami Shillony, Revolt in Japan: the young officers and the February 26, 1936 Incident, Princeton, NJ: Princeton University Press, 1973.

24 This is one of the points made by Gordon Mark Berger in his history of the continuities in the political party system during this period, Parties out of power in Japan, 1931-1941, Princeton, NJ: Princeton University Press, 1977. 
approach to empire-building drew Japan further and deeper into a series of military conflicts in China. In the wake of military action, diplomacy scrambled to calm the protests of regional stakeholders but, when this failed, Japanese statesmen announced the inauguration of 'autonomous diplomacy' and walked out of the League of Nations in 1933. Both the metropolitan endorsement of military action after the fact and the dismissal of Great Power objections signalled a sharp departure from the tenets of foreign policy observed since the late nineteenth century, which had always preceded military action with careful diplomatic preparations. In this way, 'fascism from below' in Manchuria succeeded where what Hugh Byas called 'government by assassination' in Tokyo failed, and brought about a military takeover of the empire that preceded the rise of the army as the 'premier power broker in Japan'. ${ }^{25}$

One key to the Manchurian success was the army's highly effective management of the mass media, something that helped to sell both the Manchurian invasion and its political leadership at the same time. Drawing on lessons of the 1920s, the army undertook a large-scale 'campaign to spread the idea of national defence' in 1931-32, aiming to create political support for army goals. Conceived prior to the Manchurian Incident, the campaign took off in the wake of the invasion. The army sponsored speech tours, rallies, parades, newsreel screenings, and radio events to take their message to the people. In one month after the Manchurian Incident, 1.7 million people attended nearly 2,000 events nationwide. ${ }^{26}$ The commercial media and entertainment industries picked up the army message of 'the national emergency' and saturated print, stage, and screen with army-sponsored 'infotainment' on the campaigning in Manchuria. Stirring tales of swift Kwantung Army action to dispatch the hapless Chinese troops, of brave and loyal Japanese soldiers, and of Japan's righteous campaign to 'defend the Manchurian lifeline!' made their way from army press releases on the front pages of the newspapers into popular war dramas in a matter of weeks. For the first six months of 1932, theatres and movie houses filled their bills with productions such as 'The glittering national flag', 'The first step into Fengtian - South Manchuria glitters under the rising sun', 'The four heroic human pillars', 'The gallant bugler', and 'Go to the front, boys!' ${ }^{27}$ The Manchurian Incident war fever stirred up by the army and the mass media spread the message about crisis in the empire, the heroism of battle, and the glory of sacrifice. All this served to convert hyper-militarism in Manchuria into support for military leadership at home.

One of the architects of army propaganda and a visible public face for the military was Araki Sadao, who occupied the key posts of Army Minister from 1931 to 1934 and Minister of Education in 1938-39. Araki served with the Kwantung Army during the First World War and led an infantry regiment during the Siberian Intervention, when he was also sent on secret reconnaissance missions into the Russian sphere of influence in North Manchuria and into Russian Siberia. He was a fervent anti-communist and Russophobe, and became a leading advocate of war with the Soviet Union in the late 1930s. Araki was an enabler of coup attempts and political violence among the group of junior officers who enjoyed his patronage. He publically defended the assassins of Prime Minister Inukai Tsuyoshi (in whose cabinet he had served) as 'irrepressible patriots', claiming: 'They acted neither for the sake of fame nor

25 Hugh Byas, Government by assassination, New York: Knopf, 1942. 'Premier power broker' comes from Edward J. Drea, Japan's imperial army: its rise and fall, 1853-1945, Lawrence, KS: University of Kansas, 2009 , p. 189.

26 Young, Japan's total empire, pp. 130-40.

27 See reviews of these productions in Eiga to engei (Film and Stage), January-June 1932. 
gain nor treason ... [but] upon the genuine belief that this was for the interest of the imperial country. ${ }^{28}$ A jovial and charismatic figure, Araki was lionized by journalists and he thrived on the media spotlight, appearing constantly in the news and on the radio, and even in the movie Japan in the time of emergency (1933). ${ }^{29}$ Like those of many prominent military leaders in the 1930s, his career circulated him through networks of state institutions that guided military policy at home and abroad. His ideas were incubated in the conspiratorial fever swamps of Kwantung Army activism; he helped orchestrate the outbreak of war fever and the rise of military radicalism at home. Men like Araki served as channels for the transmission of hypermilitarism from Manchuria to Japan.

Though Araki was purged in 1936 with the rest of the radical officers linked to the 26 February Incident, during his tenure from 1931 to 1934 he pumped up the military cult of the emperor known as the 'imperial way', at the very time when the restoration of the Manchu emperor and the 'Kingly Way' were being rolled out in Manchuria. Using the term 'imperial army' (kogun) in place of the earlier 'national army' (kokugun), he invoked the idea of a unique 'Japanese spirit' tied to the principle of ikkun banmin - the organic and direct connection between the emperor and the people that achieved its fullest expression in the special relationship between army and emperor. This formulation likewise resonated with the ideology of the Kyōwakai in Manchukuo.

A central player in the army's creation of new war heroes such as 'the three human bombs' (three soldiers blown up in the line of duty whom the army falsely claimed deliberately sacrificed themselves), Araki's Army Ministry glorified sacrificial death on the battlefield and unwillingness to surrender as expressions of the Japanese spirit of bushido. Araki reintroduced the Japanese sword (Yasukuni-tō) as the weapon of Japanese officers in 1934, built a foundry to produce them in the grounds of the Yasukuni National Shrine to the war dead, and made a cult of the sword a central element of his push for a return to the 'Japanese spirit'. ${ }^{30}$ His ideology of the 'imperial way' thus drew on a long list of reinvented traditions: Shinto ideas of the divine land, samurai rituals of sacrifice on the battlefield, and the mytho-history of the family state that unified emperor and subject.

Such reinvented traditions became core elements of wartime ideology that transcended longstanding doctrines of navalism and respect for military institutions or even the celebrations of Japan's continental wars in popular culture. ${ }^{31}$ With its apotheosis of Japanist military spirit and an aestheticization of military violence, the ideology of the 'imperial way' departed from the ideas of military-led modernization instilled in the late nineteenth century. It naturalized a false choice between wars of aggression and national suicide. At the same time, the radical movement among the young officers and their more senior enablers sought to overturn the established political order, taking another pass at the Meiji Restoration of imperial power of 1868 in order to renovate and revitalize the imperial state through a Showa restoration. The army became an

28 Ogata, Defiance in Manchuria, pp. 153-5.

29 Naomi Ginoza, 'From dissonance to affinity: an ideological analysis of Japanese cinema in the 1930s', PhD thesis, UCLA 2007, pp. 55-119.

30 Drea, Japan's imperial army, pp. 171-4.

31 For popular cultures of war prior to 1931, see Donald Keene, 'The Sino-Japanese War of 1894-95 and Japanese culture', in Donald Keene, Landscapes and portraits: appreciations of Japanese culture, Tokyo: Kodansha International, 1971, pp. 259-99; Naoko Shimazu, Japanese society at war: death, memory and the Russo-Japanese War, Cambridge: Cambridge University Press, 2009; and J. Charles Schencking, Making waves: politics, propaganda, and the emergence of the Imperial Japanese Navy 1869-1922, Stanford, CA: Stanford University Press, 2005. 
instrument of radicalism and terror; it seized control of Japan's sphere of influence in China and took over the state from within at home. Together with Asian-style fascism, the rise of hyper-militarism in Manchuria and Japan thus helped create the phenomenon of fascist imperialism. And, much as Asianism was an expression of the regional geopolitics of anti-colonial nationalism, hyper-militarism connected repression at home to aggression abroad, the inside and the outside of fascist imperialism.

\section{Red peril and the politics of fascist imperialism}

Red peril emerged as another key feature of fascism in Japan, expressed in increasing state focus on the internal and external dangers posed by the spread of communism. Fascist thought linked communism to an existential threat to the national body (kokutai), a term redolent of emperor-centred mysticism that became the centrepiece of new forms of propaganda and censorship. Legal and institutional structures anchored to the Peace Preservation Law of 1925 connected communism with treason and authorized the expansion of a police state. At the same time, rising concerns with Comintern activism in the empire, antagonistic Soviet foreign policy in Asia, and the military threat posed by the Red Army helped drive Japanese diplomacy into an alliance with Germany and Italy. For Japan, the diplomatic, military, and political challenges of Russian communism converged in the rapidly evolving situation in China, which became ground zero for the rise of fascist imperialism to counter the challenge.

Though anti-Russian sentiments went back to the imperial rivalries of the nineteenth century, the events of the 1910s and 1920s infused this historic sense of antagonism with a new feeling of peril. Across Europe and Asia, the radical right grew in tandem with the radical left, as international and national socialist movements accelerated during the First World War. The Russian Revolution sent shock waves around the world, giving inspiration to activists on both sides of the political divide. The newly established Soviet Union issued a challenge to the diplomacy of imperialism, exposing the perfidy of the Allied powers with the publication of the secret treaties. Apprehensions about the potential for Soviet Russia to destabilize regional alliance systems were heightened by the creation of the Comintern in 1918, which sent money, advisors, and organizational strategies to scores of countries in order to spread revolution. Communist party organizations throughout Asia worked closely with Soviet advisors and scholars, who provided military training and other forms of assistance to Chinese nationalists in the 1920s and helped establish the Japan Communist Party. Social networks of Japanese, Chinese, Korean, and Russian communists circulated throughout East Asia and the Japanese empire, policed unevenly, though with increasing intensity, over the course of the 1920s, 1930s, and 1940s. ${ }^{32}$ Paranoia about the 'red peril' ran rampant among political, economic, and military elites, for whom the spectre of the Russian Revolution and their conviction that Japan could easily descend into chaos and revolution impelled the expansion of a police state in

32 Chalmers Johnson, An instance of treason: Ozaki Hotsumi and the Sorge spy ring, Stanford, CA: Stanford University Press, 1990. On the Comintern and the Chinese Communist Party, see Ishikawa Yoshihiro, The formation of the Chinese Communist Party, trans. Joshua A. Fogel, New York: Columbia University Press, 2013; Otto Braun's autobiography, A Comintern agent in China, 1932-1939, Stanford, CA: Stanford University Press, 1982; and the classic study by Benjamin I. Schwartz, Chinese communism and the rise of Mao, Cambridge, MA: Harvard University Press, 1951. On Comintern activism from the Japanese perspective, see Akira Iriye, After imperialism: the search for a new order in the Far East, 1921-1931, Cambridge, MA: Harvard University Press, 1965; and Marius B. Jansen, The Japanese and Sun Yat-sen, Cambridge, MA: Harvard University Press, 1954. 
the mainland and the colonies. The perception of both external and internal threats fuelled the rise of fascist ideas as an alternative vision of radical reform and a counterweight to communist power.

The confrontation between communism and anti-communism became a powerful driver of a politics of fascism within the home islands. Beginning in the late 1920s, fears of the enemy within prompted a rapid expansion of police powers and robust political support for this within the Imperial Diet. Under the authorization of the Peace Preservation Law of 1925, the state expanded the powers of the Special Higher Police, extending branches to every prefecture of Japan and those places abroad where there were overseas Japanese communities. ${ }^{33}$ A new division to focus on subversive (communist and socialist) thought was also added, leading to the moniker 'thought police'; and an extensive network of informants and internal spies was recruited to keep tabs on radicals. Thus, fears of communism provided the motive and justification for political repression and the creation of fascist-style police powers from the late 1920s, as internal surveillance, mass arrests, purges, and the forced recantations of left-wing beliefs became part of the toolkit of governmentality.

The Japan Communist Party was largely crushed by these mechanisms in a series of mass round-ups in 1928 and 1929, and again in 1932-33. Nevertheless, Marxism remained influential among the intellectual elite in universities, think tanks, and highbrow journalism. Even when right-wing activists, working in coordination with government agencies, organized campaigns against 'subversive thought' and 'lèse-majesté' to drive liberal and left-wing scholars from their university teaching posts, many left-wing intellectuals managed to find work in state-sponsored research institutes and were even able to continue some of their research as long as they either publically recanted their beliefs or practised self-censorship to eschew overt criticism of state. Think tanks that provided research and advice to government agencies such as the Shōwa Kenkyūkai and the Tōa Kenkyūjo were havens for suspect intellectuals. The Research Department of the SMR expanded sharply in the late 1930s to absorb its new role as economic planning hub for the yen bloc and had a staff of 2,300 researchers at its peak, many being well-known leftists from Japan. ${ }^{34}$

What becomes clear in the case of the suppression of communism within Japan and the migration of leftists to Manchuria is the importance of the empire in the operations of the anti-communist police state. Throughout the 1930s and even into the 1940s, Manchuria represented what one contemporary called an 'intellectual time zone change' for Japanese intellectuals and an escape valve to let off pressure from the excesses of political repression in Japan. $^{35}$ Moreover, this escape valve became an important element in the intellectual foundation of Manchukuo. Leftist scholars working for the SMR provided research for the Kwantung Army and the Manchukuo government, and helped draw up the five-year plans for Manchurian development based on the Soviet command economy. Convinced that the decimation of the Japan Communist Party by 1933 made revolutionary action all but impossible within Japan, Marxist intellectuals shifted their hopes to Manchuria, where they sought to stage a 'revolution from above' through their influence with the Japanese rulers of

33 Elise K. Tipton, The Japanese police state: the Tokko in interwar Japan, Honolulu, HI: University of Hawai ${ }^{i}$ Press, 1990.

34 Young, Japan's total empire, p. 278.

35 Joshua Fogel, 'Introduction: Itō Takeo and the research work of the South Manchurian Railway Company', in Itō Takeo, Life along the South Manchurian Railway: the memoirs of Itō Takeo, trans. Joshua Fogel, Armonk, NY: M.E. Sharpe, 1988 , p. xvi. 
Manchukuo. Much of their effort was directed to organizing the Chinese peasantry into agricultural cooperatives and the Kyōwakai, working with the Kwantung Army to carry out the 'liberation of the Asian peasant masses'. Pursuing their revolutionary goals under the slogans of racial harmony and the Kingly Way, leftist refugees of the metropolitan police state helped make Asian-style fascism in Manchuria. For its part, the Kwantung Army kept its powder dry, leaving most of these intellectuals in their jobs and forbearing to deploy the instruments of repression at its disposal.

Though the leftists were convinced that they could flip the script and redirect the policies of the Manchukuo state towards colonial revolution, this was a dangerous game. As the fortunes of war turned against Japan, an increasingly paranoid leadership focused their attention on potential traitors in their midst. The efforts of leftist intellectuals on behalf of the Chinese peasantry in Manchuria aroused the anti-communist paranoia of the Kwantung Army, who, in search of a scapegoat, unleashed the fury of the colonial police state upon them. In an 850-page internal investigation on 'The communist movement of Japanese in Manchuria', the Kwantung Army claimed to have uncovered a massive communist conspiracy in Manchuria. Meanwhile, in Japan, the spectacular discovery of a Russian spy ring that reached the highest levels of government touched off an anti-communist witch-hunt. ${ }^{36}$ In November 1941 military police arrested some fifty SMR researchers, the first in the wave of arrests that decimated the Research Department in 1942 and 1943, swept up liberal and left-wing intellectuals in Manchuria, and purged the elite publishing world and government think tanks in Japan, as the government tried to make a clean sweep of suspect scholars.

These red purges in the last years of the war revealed the connection between the politics of anti-communism at home and in the empire. A crackdown by the expanding police state in the early 1930s led to an outflow of leftists to the empire; but when red paranoia broke out in Manchuria it quickly spread back home, where it raged out of control in the final years of the war. In this way, anti-communism constituted fascist imperialism as a political field and a form of police state. It connected empire and metropolis through social networks of elite intellectuals and foreign policy officials, through the politics of fear and scapegoating, and through the tactics of internal surveillance and the purge.

Another way in which anti-communism became central to fascist imperialism was through the strategic thinking and geopolitical vision of Japan's wartime leaders. The potency of 'red peril' in military doctrine traced its roots to a long-standing Russophobia, itself nurtured in the rivalry for control over Manchuria and Korea from the turn of the century and heightened during the Russo-Japanese War and its aftermath. ${ }^{37}$ The Portsmouth Peace Treaty of 1905 forced Russia to transfer rights and interests in South Manchuria, originally signed over by China in 1898. These included the balance of a twenty-five-year leasehold over the Liaodong Peninsula, with a network of ports, bases, railways, and military prerogatives. Until 1931 Russia retained a sphere of influence in Northern Manchuria, anchored to the remaining portions of its railway empire. In the face of Japanese military action in the early 1930s, the Soviet Union retreated north to Siberia, where it began to build up military defences along the Manchuria-Siberia border. Convinced that a revenge attack was a matter of time, the Kwantung Army built up its own forces in return and prepared for a showdown against the USSR.

36 Ibid., pp. xxi-xxv.

37 Peattie, Ishiwara Kanji, pp. 3-27. 
With both forces on heightened alert, Kwantung Army forays into Soviet territory provoked border skirmishes that flared into undeclared war in the Changkufeng and Nomonhan Incidents of 1938 and $1939 .{ }^{38}$

The Japanese Army broadcast their fears in propaganda pamphlets and public speeches on 'red aggression' (akka shinryaku). As a 1932 pamphlet declared:

The aggressive character of the Russian people is no different under the Soviet Union from the Tsar. For Russians aggression is their temperament and their national policy ... Since the establishment of the Soviet Union, without a single day of rest, the Russian people have ... spread the evil of Bolshevism everywhere ... and the poison has even seeped into the Japanese empire.

The army warned that Soviet five-year plans were integral to a plan to Bolshevize Asia and aimed at 'strengthening national defence and preparing for war'. Therefore Japan 'must be on the alert for military aggression' and other machinations to attack 'imperial Japan through economic disruption or inciting Chinese and Koreans to spread evil ideas'. ${ }^{39}$ Red peril thus fused internal and external threats across the Japanese empire.

As the history of Japanese expansionism in China demonstrates, anti-communism dictated a wide range of policies, from military doctrine to diplomatic alliances to political strategy. Much like Asian-style fascism and hyper-militarism, anti-communism fuelled fascism via the connections between geopolitics, colonial politics, and domestic politics. The ubiquity of red peril thinking at these multiple sites of state action was both cause and effect of the turn to fascist imperialism. Moreover, red peril thinking intensified when it appeared to fuse internal and external threats from suspect intellectuals advising the Kwantung Army and their former classmates working in state think tanks in Tokyo. Fascist imperialism helps explain the potency of anti-communism for wartime Japan, its woolly and protean quality, and why it became so central to the fascist governmentality of the police state.

\section{Radical statism and the spatial fix of fascist imperialism}

What Asian-style fascism, hyper-militarism, and red peril all had in common was the turn to the state as the agent of salvation, and the emergence of what I call 'radical statism'. Radical statism expressed an unquestioned faith in the omnipotence of the state, and fetishized action, movement, and force. It sanctioned the rapid growth of state powers to carry out multidirectional reforms. It created an intellectual space where left, right, conservative, and liberal could meet in agreement on the need for state solutions - a bed where they could all 'dream their separate dreams'. And it dissolved the line between metropole and empire: the spectral possibilities of unlimited action in the empire and the dictatorial powers of the colonial state fed the magical thinking about what the metropolitan state might accomplish if pressed to act.

38 The definitive study is Alvin D. Coox, Nomonhan: Japan against Russia, 1939, Stanford, CA: Stanford University Press, 1985.

39 Rikugunshō (Army Ministry), 'Hakka ni sonaeyo (Guard against the white peril!)', 1932, one of a series of propaganda pamphlets issued in the 1930s, held in the archives of the National Institute for Defense Studies, Tokyo. For discussion of the pamphlets, see Eguchi Keiichi, 'Manshū jihenki no Rikugunshō panfuretto (The Army Ministry pamphlet campaign during the Manchurian Incident)', Hōkei ronshū (Aichi Daigaku) (Aichi University Review of Law and Economics), 113, February 1987, pp. 165-97; Young, Japan's total empire, pp. 140-9. 
Driving the embrace of radical state solutions were events on the world stage. Triggered by the rise of anti-colonial nationalism and its challenge to liberal imperialism on the one hand, and the global financial crisis of 1929 and its challenge to free trade on the other, a rising chorus of voices called for the overturning of a liberal world order that no longer worked in Japan's favour. Government spokesmen and public intellectuals lambasted limits on Japanese migration, Japanese exports, and Japanese expansion as a hypocritical effort on the part of status quo ('have') powers to seal off parts of the world from the legitimate interests of rising ('have not') powers such as Japan. Ideas about living space, the Manchurian lifeline, a Monroe Doctrine for Asia, and yen bloc autarky gained traction as justification for expanding into China. Increased control over land, labour, and resources in Manchuria would provide a spatial fix for Japan's problems with the liberal world order. One component of this spatial fix was state-led development of Manchuria to complement resource-poor Japan, provide an outlet for domestic industry, and create a self-sufficient trade and production sphere. A second component was the linking of agrarian reform in Japan and Manchuria, solving rural poverty and the crisis of capitalism in Japan's countryside through planned migration and the creation of state-managed farm cooperatives in Manchukuo. In both cases the state constituted the central agent of radical reform.

The first of these programmes was called the 'controlled economy' (tosei keizai), which drew inspiration from German total war doctrine and the Soviet command economy to develop economic policy for the national defence state. ${ }^{40}$ Beginning with the Manchurian Incident in 1931, the escalating war effort provided justification for a continual expansion of state power along these lines, remaking the state into a fascist form through state directives on production targets and commerce that limited the free market, through public-private partnerships and cooperatives that crowded out private industry, and through strident anti-capitalist rhetoric. This began in Manchukuo, was later applied to state structures based in Tokyo, and eventually included empire-wide coordination that recast the national defence state as a national defence empire. Newly created organs of the Manchukuo state became a training ground for a new breed of technocrats who used colonial autocracy to institute a series of controls on the free market and private industry and to test out the mechanisms of the national defence state. Manchukuo incubated the so-called new zaibatsu (large financial-industrial combines that dominated the Japanese economy), new officers, and new bureaucrats - the technocratic elites who developed key policy programmes that defined this project. ${ }^{41}$

The move to a controlled economy in Manchukuo represented a significant departure from twenty-five years of highly profitable economic activity under the direction of the SMR. Zaibatsu such as Mitsui and Mitsubishi benefited from Japan's railway empire and drew heavy profits from handling exports of Manchurian soybeans, which constituted $75 \%$ of SMR revenues and half of the world supply. ${ }^{42}$ Japan's railway empire in Manchuria enjoyed enormous success under a regime of liberal imperialism. When the Kwantung Army took over Manchuria in the early 1930s, the military also assumed control of the SMR and turned the company into a vehicle for the Kwantung Army's experiment with the controlled economy.

40 Mimura, Planning for empire, esp. pp. 70-106.

41 For more on the planned economy in Manchuria, see Chalmers Johnson, MITI and the Japanese miracle: the growth of industrial policy: 1925-1975, Stanford, CA: Stanford University Press, 1982, pp. 83-156. 
In the process they abandoned what had proved a highly profitable model of an extractive colonial economy tied to global markets, in exchange for regional autarky and colonial state developmentalism. ${ }^{43}$

The Manchukuo state redirected company assets into an ambitious project to establish strategic military industries in China and Korea through a series of government plans for Manchurian development. The army signalled to the business community that Manchukuo would not be a venue for capitalism as usual. As Araki Sadao announced, they intended to 'exclude monopoly profits' from Manchuria; 'zaibatsu will be kept out'. ${ }^{44}$ The Manchukuo government's Economic Construction Programme of 1933 began to establish state control over economic activities, and each year the scope and ambition of state plans for economic development increased. State planners established a list of types of industries that were subject to escalating levels of state management. Public utilities and industries related to national defence were reorganized into state-managed, privately owned companies; other industries were simply regulated. ${ }^{45}$ Manchukuo officials created twenty-six new companies by the end of 1936, when the army enticed Ayukawa Gisuke, president of the new zaibatsu Nissan, to move his operations to Manchuria and establish Manchurian Heavy Industries as the vehicle for the controlled economy.

The Manchukuo government directed Manchurian Heavy Industries to run the Manchurian economy under the principle of one sector, one company, and they established the mechanisms for public-private collaboration. They set carefully projected targets for production and trade within the yen bloc, envisioning the reorganization of the empire into an autarkic bloc economy - a spatial fix for resource-poor Japan and an exit ramp from the constrictions of liberal world trade and free-market capitalism.

In addition to the controlled economy, to address the demands of national defence and the limitations of the liberal world market, radical statism embraced a programme of agrarian communitarianism to respond to equally challenging conditions in the rural social economy. Japan engaged in an ambitious experiment with population control, where Manchukuo became a laboratory for the creation of new forms of community, cleansed of the corrosive divisions of capitalist society. Settlement policies across the Axis empires displaced millions of people, as state planners offered various combinations of enticements and compulsions to relocate populations and remake the alignments between land and people, blood and soil under a fascist vision of national community. Japan's version of imperial resettlement was represented in the 'Millions to Manchuria' plan to export impoverished tenant farmers to Northeast China, remaking the socioeconomic landscape of Japan's troubled rural villages as it constructed model cooperative farm communities in the putatively empty plains of Manchuria. Though the blueprint for Japanese farm colonization differed in its particulars from German labour policies or Italian plans for a fourth shore in North Africa, what they shared was the reliance on state planning, the scope and speed of the resettlement, and the creation of a massive state bureaucracy to manage population movement and labour organization throughout the empire.

43 On the SMR, see Yoshihisa Tak Matsusaka, The making of Japanese Manchuria, 1904-1932, Cambridge, MA: Harvard University Asia Center, 2001.

44 Young, Japan's total empire, p. 196.

45 South Manchurian Railway, Fifth report on progress in Manchuria to 1936, South Manchurian Railway Company, 1936, p. 98. 
The Manchurian solution to the 'problem of the villages' arose against the backdrop of a seemingly intractable rural crisis. ${ }^{46}$ Accelerating disputes between tenants and landlords over the course of the 1920s and persistent problems with high levels of household debt had resisted solution. The global reverberations of the Wall Street Crash of 1929 dealt the rural economy a stunning blow. Petitions poured into the capital begging for help and the government convoked a special 'save agriculture' session of the Imperial Diet in 1932 to address the problem. Against the record of failed initiatives to solve problems of farm debt and minute-scale agriculture, as well as the unwillingness of the politically connected landlords to make concessions to tenant demands, the Manchurian solution took shape. Class tensions, inadequate financial markets, contradictions in the land tenure system: the crisis of capitalist agriculture would be solved by exporting the 'excess population' of rural poor to agricultural land in Manchuria, forcibly appropriated from Chinese and Korean farmers.

In 1936 the Hirota cabinet adopted Manchurian colonization as one of the pillars of national policy. Government plans envisioned sending five million farmers - an estimated $20 \%$ of the rural population - to the new world in Manchuria over a twenty-year period. With a generous budget and an army of civil servants, the Colonization Bureau in Manchuria and the Rural Rehabilitation Movement in Japan undertook to socially engineer harmonious farm communities. ${ }^{47}$ Like the controlled economy, migration made the state into the spear tip and staging ground for radical reform. New organs of executive power ran large-scale social scientific surveys and issued mountains of reports, deploying legions of experts to plan and carry out the depopulation of rural Japan. All this became a mechanism for the fascization of the state.

Yoked to a phantasmagoric empire of empty, fertile land and infinite resources, radical statism offered up a spatial fix of boundless possibility. Incubated in the hothouse of colonial state authoritarianism, state power exaggerated its own potential. The colonial origins of radical statism led to a seductive vision of omnipotent force and decisive action to break through the deadlock, a prospect that convinced stakeholders to grow the instrumentalities of state power and authority. In this sense, radical statism signified a kind of gigantism: a build-up of bureaucratic capacity to manage labour, migration, trade, and production. Finally, radical statism set the state above politics. On the one hand, it overcame bureaucratic factionalism through sheer momentum. On the other, it made technocracy into a bridge between the antagonisms of scientific socialism and national planning, between Soviet and Nazi sciences of the state.

\section{Conclusion}

Where does this leave our thought experiment on fascism in Japan? This article has argued that fascist imperialism emerged from three conditions. First, the First World War signified a sea change for regional geopolitics in Asia. Three main regional political forces - anti-colonial nationalism in China demanding the end of gunboat diplomacy and the return of sovereignty; the

46 Kerry Smith, A time of crisis: Japan, the Great Depression, and rural revitalization, Cambridge, MA: Harvard University Asia Center, 2001.

47 For more on this history, see Gregory Paul Guelcher, 'Dreams of empire: the Japanese agricultural colonization of Manchuria (1931-1945) in history and memory', PhD thesis, University of Illinois at Urbana Champaign, 1999. 
crisis in the liberal economic order of free trade and global capitalism; and the demonstrated success of the Russian Revolution as an alternative model for a worker state - combined to drive the turn to fascism in Japan, a political shift that came fast and hard. Second, the military occupation of Manchuria and the process of state-making and nation-building in Manchukuo generated a stream of fascist technologies and methods, ideas, and organization models. Key elements of Japanese fascism were incubated within the hothouse of colonial governmentality, where the state was free to act at will. The colonial provenance of numerous fascist ideas and impulses helps explain their shocking cruelty and despotism. Third, fascism emerged out of the concatenation of internal and external causes and forces. The creation of a controlled economy in Manchukuo made it possible to expand state controls over the economy within the main islands. The development of a fascist-style police state within the main islands made it possible to deploy similar strategies across the empire. The expanding stake in the empire in China and Southeast Asia across the 1930s and 1040s accelerated and reinforced the mutual constitutions and entanglements of fascist imperialism. In this sense, fascism represented the synergy of colonial and metropolitan polities.

In exploring the meeting of fascism with empire in Japanese-occupied Manchuria, this article has highlighted the centrality of the imperial connection in the rise of global fascism during the 1930s. A theory of fascist imperialism starts here, with the expansionist drive at the heart of fascism: in the elemental connection between aggression abroad and repression at home; and in the recognition that the ideology of the 'have not' nation is an ideology of expansionism. Fascist ideas interacted with anti-colonial nationalisms and gave rise to new forms of sovereignty such as the client states of the Co-prosperity Sphere. Japan's delicate finessing of the sovereignty issue became central to fascist forms of colonial control such as mobilization of subject populations through mass parties, as well as the autarkic yen bloc and a pan-Asian union of client states that together claimed to liberate the East from the white peril of Western despotism. Radical fascist experiments in state power were tested at will under the dictatorial colonial state in Manchukuo, before statism gradually dispensed with democratic controls at home. Representing itself to other Asians as an avatar of the true revolution, fascist imperialism claimed to repudiate the bankrupt 'diplomacy of imperialism' on the one hand and the false idol of Comintern liberation theology on the other. In the end, one might argue that the fascist project forged in the crucible of empire led to the imperial overreach that destroyed it - though this certainly did not make fascist imperialism unique. Putting Japan and Asia into the mix, and asking the question 'What set Japan, Germany, and Italy apart from other empires during the global conjuncture of the 1930s?' suggests that we can productively open up and rethink the problem of fascism, even after nearly a century of study.

The issue is of some urgency as we confront the current conjuncture. Much as an enfeebled liberal world order of the 1920 s gave rise to fascism at an earlier moment, the bankrupt promise of neo-liberalism has led to new forms of right-wing populism that traffic in neo-fascist ideas. This suggests that we need to keep our eye on the international arena to understand why similar ideas might gain traction in a variety of places at this moment of global crisis. Though many explanations for sharp political turns offer themselves in the weeds of local conditions, it is the concatenation of internal and external crises and the seeming convergence of the rise of a global right that demands a broader framework for analysis. One might fruitfully examine the global and local structures of neo-liberalism that emerged amid the wreckage of the Bretton Woods system of state-managed international finance, as well as the discourse on free-market 
fundamentalism and its discontents. One might also look at the global phenomenon of blowback from empires old and new, and the unintended consequences of wars hot and cold that have continued into the new millennium.

Louise Young is Vilas Distinguished Professor of History at UW-Madison. Her work focuses on modern Japan, especially social and cultural history. She is the author of Japan's total empire: Manchuria and the culture of wartime imperialism (1998) and Beyond the metropolis: second cities and modern life in interwar Japan (2013). 